\title{
Protection of Scots pine planting stock and forest plantations against diseases and pests in Belarus
}

\author{
Sergei Prahodsky ${ }^{1}$, Valery Kaplich ${ }^{2}$, Dmitry Voitka ${ }^{3} \bowtie$ \\ ${ }^{1}$ Belarusian State Technological University, Department of Landscape Design and Architecture, Sverdlova 13a, \\ 220006, Minsk, Belarus \\ ${ }^{2}$ Belarusian State Technological University, Department of Tourism and Nature Management, Sverdlova 13a, \\ 220006, Minsk, Belarus \\ ${ }^{3}$ Institute of Plant Protection, Laboratory of Microbiological Method of Plant Protection against Pests and Diseases, \\ Mira 2, 223011, ag. Priluki, Minsk region, Belarus, e-mail: d.voitka@tut.by
}

\begin{abstract}
The aim of this research is the monitoring of diseases of Scots pine in the plantings and forest stands in the Republic of Belarus depending on the species composition of pests, their biology and the effectiveness of various methods of plant protection. Significant loss of plants for planting is associated with the spread of pathogens causing damage to seedlings, mainly from the genus Fusarium, Alternaria and Botrytis. The most abundant pests of Scots pine are Coleoptera and Lepidoptera groups representing 16 and 8 species, accordingly. Numerous species represent Curculionidae, Scarabaeidae and Tortricidae family. The main components of an effective system of measures, as an integral part of the technology of growing of planting material of Scots pine in containers, are pre-sowing seed treatment with fungicides, stimulating the growth and development of seedlings. The elaborated system of protective measures of forest plantations is based on the prevalence, phenology of pests, estimation of phytopathogenic load, monitoring of diseases and seasonal climatic conditions.
\end{abstract}

\section{KeY WORDS}

Scots pine, seedlings, planting material, forest plantations, diseases, pests, control

\section{INTRODUCTION}

Currently, the program of forest nurseries development in the organizations of the Ministry of Forestry of Belarus planned to build 15 new permanent forest nurseries covering about 118 hectares with the aim of growing the planting material in the protected ground with closed root system for planting and landscaping.
The technology of growing seedlings in containers solves the season's problem, as well as to achieve maximum germination and seedling size at a high survival potential. However, different from the external environment, greenhouse conditions favour the development of pathogens, reducing the germination, seedling growth and often leading to their death. So, during the first month of cultivation, mortality can reach up to $60 \%$ and more. 
Germinating seeds and shoots of woody plants are not very resistant to the effects of pathogens due to the herbaceous state of organs and tissues. Consequently, from the moment the seed enter the substrate, they need careful protection (Ryabinkov 2006; Clothier 2009). Among the main diseases of Pinus sylvestris L., which appear in nurseries, the most harmful is damping off seedlings (Vedernikov 2002; Kavosi 2006; Sokolova and Galasyeva 2008). The disease becomes especially dangerous in conditions of greenhouse, where plants grow in containers. The causative agents of this disease are micromycetes of the genera Fusarium, less often Alternaria, Verticillium, Rhizoctonia, Botrytis, Pythium, Pestalotiopsi or, Cylindrocarpon (Vaartaja 1964; Dishuk and Kobzarova 2008; Sokolova and Galasyeva 2008; Keller and Oak 2009; Yarmolovich et al. 2015) and oomycetes from the Phytophthora genus. As the main pathogens in nurseries, the species of Fusarium dominate (Sokolova 2008; Churakov and Churakov 2007).

Concerning insects or pests of planting material of coniferous species grown under protected soil conditions, scientific data are not available in the literature. This is more likely due to the isolation of plants from the external environment and the specific conditions that arise in the production areas of greenhouses. Analysis of literature data shows that the most dangerous for seedlings in greenhouses are pests of buds and shoots from Tortricidae family: pine-shoot moth Evetria (= Rhyacionia, Retinia, Grapholitha) buoliana Denis\&Schiffermuller), pine resin-gall moth E. resinella $\mathrm{Hb}$. and also E. duplana $\mathrm{Hb}$., E. turionana $\mathrm{Hb}$., and also the pests of roots - leaf-horned beetles (Scarabaeidae) (Vorontsov 1982; Zolubas 1999). In Belarus, conditions Melolontha hippocastani Fabr. and Melolontha melolontha L. are widespread; however, Polyphylla fullo L., Phylloperta horticola L. and Serica brunnea L. also occur, but less frequently (Vorontsov 1982; Kharitonova 1994).

Economic losses caused by pests and phytopathogens of planting material prove a need for an efficient protective measures to be implemented in the Belarus nurseries. This research focuses on the evaluation of application of pesticides against pests and pathogens.

\section{MATERIAL AND METHOdS}

Phytosanitary study of Scots pine were held at the National Forest Breeding and Seed Centre (NFBSC), on the test plots in the forest cultures, the first age class and the routing method in three geobotanical subzones of Belarus. There are 164 temporary registration sites at NFBSC, in the forest cultures of Scots pine - 6 permanent and 1 temporary trial plots. In total, 1589 measurements were conducted, and 256 samples were taken for phytopathological studies at NFBSC; 630 measurements were conducted in pine forest cultures, 32 samples were taken for phytopathological studies, 752 insects were identified and 98 measurements of phytophagous were conducted by the route method, biometric parameters and phytosanitary status of 2670 trees were analysed.

In developing the protective measures system, the biological efficacy of the following pesticides, plant growth regulators and biological preparations: Lamador, SC (250 g/l prothioconazole $+150 \mathrm{~g} / 1$ tebuconazole), ) Fundazol, WP (500 g/kg benomil), Vincit, SC ( $25 \mathrm{~g} / 1$ flutriafol $+25 \mathrm{~g} / \mathrm{l}$ thiabendazole), Vitaros, WSC (98 g/l tiram + $198 \mathrm{~g} / \mathrm{l}$ carboxin), Albite, RP (6.2 g/kg poly-beta-hydroxybutyric acid, $29.8 \mathrm{~g} / \mathrm{kg}$ magnesium sulphate, $91.1 \mathrm{~g} / \mathrm{kg}$ potassium dihydrogen phosphate, $91.2 \mathrm{~g} / \mathrm{kg}$ potassium nitrate, $181.5 \mathrm{~g} / \mathrm{kg}$ carbamide), Ekosil, WE (50 g/l triterpene acids), Geteroauksin (indoleacetic acid), Fitoverm, 0,2\% EC ( 2 g/l aversectin C) and Lekanicil, L (entomopathogenic fungus Lecanicillium lecanii Zare et Gams) was assessed.

\section{Results AND DISCUSSION}

As established by our studies, the average seed dormancy ranges from 6 to 7 days with an average germination rate of $94 \%$. Sowing dates (rotation) have a significant effect on germination: in I rotation, an average of $84.7 \%$ of the seeds germinate, in II $-71.0 \%$, and in the III $-65.6 \%$. Seedlings with a closed root system, grown at the beginning of the season, have higher biometric parameters, and consequently, are resistant to abiotic and biotic factors, in comparison with the next rotations.

First phase of seedlings should be identified with the development of seedlings of Scots pine. It includes 
the development of plants before reaching the substrate surface. Plants' death from pathogens in this phase increases from 14.1 up to $48.6 \%$. Also, there is recovered phase mass germination, sprouting end, the deployment of cotyledons (death of seedlings up to $5.8 \%$ ). Significant loss of planting material are associated with the spread of infectious lodging of seedlings (fungi from the genera Fusarium Link., Alternaria, Botrytis, etc.). Since the appearance of bud, the resistance of plants to the disease causative agents is increasing.

When creating forest plantation, the planting material of Scots pine in containers also has higher rates of survival and adaptation to abiotic and biotic factors due to the well-developed root system and the absence of mechanical damage during planting. On average, the survival rate of forest plantation from the container seedlings is $93.0 \%$, while using planting material with open root system, it is $81.9 \%$.

A positive effect was obtained on lands that were released from agricultural use. The annual growth in the height of forest cultures created by planting material with a closed root system was higher in the first years than with a planting material with an open root system on average $12.4 \%$. Similar conclusions can be drawn from the analysis of the accumulation of organic matter.

When growing the planting material of Scots pine with a closed root system, the next diseases were indicated: rot, moulding and deformity, which were presented as a combination of symptoms. Under protected ground conditions, five widespread infectious agents have been detected; among these, the pathogens Fusarium oxysporum Schecht. and Alternaria alternata were dominant. Also, imperfect fungi that form touch of mould including seeds of coniferous species have been identified. Fungi of the Fusarium genus that account for more than half $(51.4 \%)$ of the affected plants, are the most common pathogens of seedlings. At the same time, in some cases (2.1\%), the pathogens of the genera Alternaria, Botrytis and Fusarium can attack plants together.

Under the protected ground conditions, from 14.1 to $48.6 \%$ of seeds do not germinate. The dead and effect of seedlings are $4.7-10.9 \%$ of the total number of sown seeds. The proportion of healthy seedlings at the end of the growing period in protected soil conditions (30-35 days) ranges from 43.6 to $81.2 \%$. The preva- lence of infective lodging of seedlings varies from $18.6 \%$ to $56.8 \%$. The prevalence of the disease reaches a maximum at sowing seeds in the summer period (III rotation).

On the forest plantations up to 10 years of age, which are created using seedlings with closed root system, diseases are widespread. The prevalence of main diseases ranges from high (11-30\%) to strong (over $31 \%$ ) the degree of injury.

Entomocomplexes of pests of Scots pine vary depending on the forest growing conditions and age of plantations (Prahodski et al. 2010). In the forest cultures of Scots pine, created by different planting material, phytophages of 33 species belonging to 6 orders and 12 families were identified (Fig. 1). The most extensive species composition are groups of Coleoptera (16 species) and Lepidoptera (8 species). Numerous in species diversity are the representatives of the families Curculionidae, Scarabaeidae and Tortricidae. Poorer in species composition are Lachnidae family, Elateridae, and others. Due to its high fertility and favourable climatic conditions phytophage Cinara pinea in Belarus reaches a maximum number of more than 50 individuals/shoot. However, the number varies during the growing season. The most intensive representatives of the genus Cinara reproduces, and consequently, also feeds in the first half and middle of the summer season. In May-June for 20-30 days, its population increases 6-9 times. Colonies of brown pine aphids can cause a backlog in the growth in height of Scots pine on $6.1-11.1 \%$ for the first five years after its establishment.

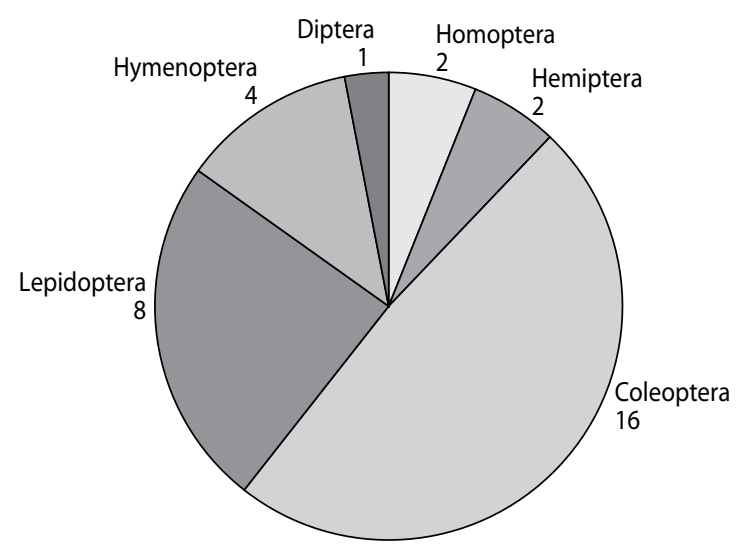

Figure 1. The specific structure of Scots pine forest plantations phytophagous 
Based on the above, the system of protective measures should be aimed at limiting the development and spread of infectious lodging of seedlings, regulation of the number of sucking pests from Lachnidae family. In this regard, we have conducted experimental studies of the effectiveness of pesticides and growth regulators, taking into account the ecological and biological characteristics of plant pathogens and phytophages.

It has been established that fungicides inhibit the growth and development of seeds (Prahodski et al. 2011). Against the background of fungicides, it subjects a positive effect on germination of «Lamador» $(82 \%)$ and «Fundazol» $(84 \%)$ is noted and the most appropriate data is recorded using the fungicide «Vincit» (89\%).

Among the growth factors, the positive effects are mentioned in variants with «Albite», «Ekosil» and «Geteroauksin»; for 10 days, $68 \%$ of the seeds were germinated.

Table 1. Efficiency of pre-sowing seed treatment with fungicides, Greenhouse NFBSC

\begin{tabular}{|c|c|c|c|c|c|c|}
\hline \multirow[b]{2}{*}{ Option } & \multirow{2}{*}{ 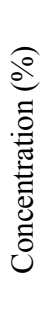 } & \multicolumn{3}{|c|}{$\begin{array}{c}\text { Amount: } \\
\text { from } 64 \text { plants } \\
\%\end{array}$} & \multirow{2}{*}{ 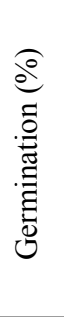 } & \multirow{2}{*}{ 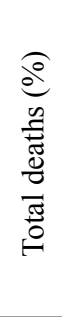 } \\
\hline & & 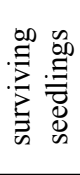 & 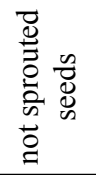 & ఫृ & & \\
\hline \multirow{2}{*}{ «Vincit» } & \multirow{2}{*}{20} & 58 & 3 & 3 & \multirow{2}{*}{95.3} & \multirow{2}{*}{9.4} \\
\hline & & 90.6 & 4.7 & 4.7 & & \\
\hline \multirow{2}{*}{ «Raksil» } & \multirow{2}{*}{5} & 55 & 8 & 1 & \multirow{2}{*}{87.5} & \multirow{2}{*}{14.1} \\
\hline & & 85.9 & 12.5 & 1.6 & & \\
\hline \multirow{2}{*}{ «Lamador» } & \multirow{2}{*}{0,1} & 60 & 3 & 1 & \multirow{2}{*}{95.3} & \multirow{2}{*}{6.3} \\
\hline & & 93.8 & 4.7 & 1.6 & & \\
\hline \multirow{2}{*}{ «Vitaros» } & \multirow{2}{*}{0,2} & 59 & 3 & 2 & \multirow{2}{*}{95.3} & \multirow{2}{*}{7.8} \\
\hline & & 92.2 & 4.7 & 3.1 & & \\
\hline \multirow{2}{*}{$\begin{array}{l}\text { «Fundasol» } \\
\text { (standard) }\end{array}$} & \multirow{2}{*}{0,5} & 60 & 4 & \multirow[t]{2}{*}{-} & \multirow{2}{*}{93.7} & \multirow{2}{*}{6.3} \\
\hline & & 93.8 & 6.3 & & & \\
\hline \multirow{2}{*}{$\begin{array}{l}\text { Water } \\
\text { (control) }\end{array}$} & \multirow{2}{*}{-} & 56 & 7 & 1 & \multirow{2}{*}{89.1} & \multirow{2}{*}{12.5} \\
\hline & & 87.5 & 10.9 & 1.6 & & \\
\hline
\end{tabular}

64 plants - number of cells in one cassette.

Field germination of seeds without treatment was $89.1 \%$ (Tab. 1), which is below the variants with fungicides using, except «Raksil» where germination was $87.5 \%$. Positive results of the preservation of seedlings by the end of the rearing period were received when the protectants «Vincit» (90.6\%), «Lamador» (93.8\%), «Fundazol» (93.8\%) and «Vitaros» $(92.2 \%)$ were used.

Intensive development of the plants was noted in the variants with «Vitaros», «Fundazol», «Vincit» and «Raksil». Planting material using the fungicides «Vincit» and «Raksil» was significantly higher than in control and other variants, the needle size was $48.9 \mathrm{~mm}$ and $47.9 \mathrm{~mm}$ against $45.4 \mathrm{~mm}$ in the control, and the diameter of the root collar was 1.8 and $1.7 \mathrm{~mm}$ accordingly against $1.6 \mathrm{~mm}$ in the control. Average height with «Vincit» exceeds the reference value of $55 \%$, with «Raksil» - by $58.2 \%$, while in other cases up to $10.1 \%$.

Among growth stimulators, the greatest positive effect in working conditions was observed with the use of «Geteroauksin» and «Ekosil».

Processing of forest plantations of Scots pine insecticides during outbreaks of mass reproduction of brown pine aphid has allowed reducing the pest population to $100 \%$. Chemical pesticides have a rapid effect, causing the death of almost all individuals of phytophages on the next day after treatment. On $3^{\text {rd }}$ day after treatment, the number of pests reduced by $89.5-97.6 \%$.

The action of biological preparations is gradual: the number of pests decreased from $3^{\text {rd }}$ to $14^{\text {th }}$ day after treatment. The biological efficacy after single application of the «Fitoverm» reaches $39.3 \%$, «Lekanicil» $-35.2 \%$. This confirms the need for multiple uses of biological preparations. Nevertheless, biological control is a prospective direction in developing a system of protective measures against pests and diseases in forestry.

Thus, at a low number of brown pine aphids (20 insects/shoot on $10 \%$ of plants), preferably using biological control agents. If the number of insect pest populations of more than 20 insects/shoot plants on $10 \%$ of plants and more, as well as the climatic conditions, are favourable for breeding phytophage, it should provide spraying plantations of Scots pine by chemical insecticides.

\section{Conclusions}

1. The system of protective measures of forest cultures created different planting materials, based on the prevalence and phenology of pests and climatic conditions of the season. 
2. Each measure in the system is based on the monitoring of phytosanitary state of forest plants and density of pathogen population.

3. The system of measures, as an integral part of the technology of Scots pine planting material growing in containers, have to include pre-sowing seed treatment with fungicides, stimulating the growth and development of seedlings, regulation of protected ground conditions (temperature $20-22^{\circ} \mathrm{C}$, humidity 60-80\%) and, if necessary, watering by fungicide solution (phenophase end of germination and expansion of seminal leaves) for diseases control.

\section{References}

Churakov, B.P., Churakov, D.B. 2007. Phytopathology: a textbook (in Russian). GOU VPO AT MSFU, Moscow, Russia.

Clothier, T. 2009. Damping-off / T. Clothier // Tom Clothier's Garden. http://tomclothier.hort. net/ page13.html. Accessed 4 December 2009.

Dishuk, N.G., Kobzarova, V.S. 2008. Diseases of sprouts and seedlings of coniferous species in forest nurseries of Belarus (in Russian with English summary). Proceedings of BGTU. Series 1: Forestry, 1 (XVI), 335-337.

Kavosi, M.R. 2006. The system of plant protection in nurseries from diseases using biological means. Ph. D. thesis, Moscow.

Keller, W.D., Oak, S.V. 2009. http://www.rngr.net/Publications/fnp/Conifer\%20and $\%$ 20Hardwood $\% 20$ D...ng\%20Off/at_download/file. Accessed 04 December 2009.

Prahodski, S.A., Kaplich, V.M., Voitka, D.V. 2011. Biological and chemical methods of protection of forest plantations of Scots pine from wood aphids (Hom- optera: Lachnidae) (in Russian). Proceedings of the International scientific-practical conference: Integrated plant protection: strategy and tactics, Minsk, July 5-8, 2011, 327-332.

Prahodski, S.A., Yarmolovich, V.A., Kaplich, V.M. 2010. Pests of Scots pine (Pinus sylvestris L.) in forest plantations (in Russian). Proceedings of scientific works of the Institute of Forests in Belarus: Problems of Forest and Forestry (ed.: A.I. Kavalevich). Gomel, 491-497.

Ryabinkov, V.A. 2006. Ecological problems in protecting planting material against fungi and ways of their solution (in Russian). Bulletin of the MSFU, 2 (44), 153-161.

Semenkova, I.G. 2004. Forest phytopathology. Proc. allowance (in Russian). Academy, Moscow, Russia.

Sokolova, E.S. 2008. Infectious diseases of woody plants: textbook allowance (in Russian). GOU VPO AT MSFU. Moscow, Russia.

Sokolova, E.S., Galasyeva, T.V. 2008. Infectious diseases of woody plants. Proc. allowance (in Russian). GOU VPO AT MSFU. Moscow, Russia.

Vaartaja, O. 1964. Chemical treatment of seedbeds to control nursery diseases. The Botanical Review, 30 (1), 1-91.

Vedernikov, N.M. 2002. Diseases of seedlings in nurseries and resistance. In: Proceedings of 5th International Conference: Problems of Forest Phytopathology and Mycology (eds.: V.G. Storozhenko, N.N. Selochnik), 7-10 (14) October 2002, Moscow, Russia, 39-42.

Vorontsov, A.I. 1982. Forest entomology (in Russian). High school, Moscow.

Yarmolovich, V.A. 2015. The cladosporiosis and alternaria blight in forest nurseries of Belarus (in Russian with English summary). Proceedings of BGTU. Series 1: Forestry, 1 (174), 203-206. 